\title{
Treatment of In-stent Restenosis with Excimer Laser Coronary Angioplasty
}

\author{
Ilgin KARACA, ${ }^{1}$ MD, Erdogan İLKaY, ${ }^{1} \mathrm{MD}$, Mehmet AKBUlut, ${ }^{1} \mathrm{MD}$, \\ and Mustafa YAVUZKIR, ${ }^{1} \mathrm{MD}$
}

\begin{abstract}
SUMMARY
Diffuse in-stent restenosis remains an important problem in percutaneous transluminal coronary angioplasty (PTCA). In this trial, we studied the early and mid-term outcomes of excimer laser coronary angioplasty (ELCA) on diffuse in-stent restenosis.

ELCA was performed in 23 patients ( 19 males). The mean length of the lesions was $14.3 \pm 3 \mathrm{~mm}$ and the mean age was $58 \pm 7$ years. The minimal lumen diameter (MLD) was measured by on-line quantitative coronary angiography. Before the procedure, MLD was $0.9 \pm 0.4$. The $\mathrm{Q} /$ non-Q-wave myocardial infarction (MI), coronary artery bypass graft $(\mathrm{CABG}), \mathrm{PTCA}$, and mortality were recorded during the procedure and at 6 months follow up.

The fluence of laser emission was $45 \mathrm{mj} / \mathrm{m}^{2}$ and the repetition rate was 25 pulses per second. Adjunctive balloon angioplasty was performed in all of the cases at a mean $7 \pm 2$ atm pressure. The procedure was successfully performed in all of the cases. Type-B dissection developed. after ELCA in 1 patient (4\%). Perforation, death, cerebrovascular accidents, emergency $\mathrm{CABG}$, PTCA or $\mathrm{Q} /$ non-Q wave myocardial infarction were not observed. MLD was $0.9 \pm 0.4 \mathrm{~mm}$ before ELCA, $1.8 \pm 0.9 \mathrm{~mm}(P<0.05)$ after ELCA, and $3.1 \pm 0.7 \mathrm{~mm}$ after PTCA.
\end{abstract}

At 6months follow up, there were 2 (8.7\%) Q-wave myocardial infarctions and 2 (8.7\%) recurrent anginal pain cases. Control angiography was obtained in 20 cases (87\%). Control angiography was not accepted by 3 patients. Their maximal exercise test was negative. Angiographic restenosis was observed in 6 cases $(30 \%)$. The rate of target lesion revascularization (TLR) was 5 of $23(22 \%)$ in the patients treated with ELCA.

It is concluded, ELCA is a safe and efficient debulking technology for treating diffuse in-stent restenosis. (Jpn Heart J 2003; 44: 179-186)

Key words: In-stent restenosis, Laser, Target lesion revascularization (TLR)

THE mechanism of restenosis after percutaneous transluminal coronary angioplasty (PTCA) is a combination of recoil, vessel remodeling, and neointimal hyperplasia. ${ }^{1,2)}$ Trials with intravascular ultrasound (IVUS) have showed that stents do prevent arterial remodeling. ${ }^{1,3,4)}$ Therefore, late lumen loss in stent seg-

From the ${ }^{1}$ Department of Cardiology, University of Firat-Elazig, Turkey.

Address for correspondence: Erdoğan Ilkay, MD, Zübeyde Hanim Cad. No: 116/6 Elaziğ, Turkey.

Received for publication July 12, 2002.

Revised and accepted August 12, 2002. 
ments is the result of intimal hyperplasia. ${ }^{5,6}$ The neointimal tissue is formed by smooth muscle cells and intercellular supportive tissue. ${ }^{7)}$

The rate of restenosis in stented lesions is in the range of $14 \%-60 \%{ }^{8-12)} \mathrm{A}$ focal pattern (lesion length $10 \mathrm{~mm}$ ) of in-stent restenosis is reported to be $22 \%$ $40 \%$ and a diffuse pattern (lesion length $10 \mathrm{~mm}$ ) to be $40 \%-70 \%$ of the stented lesions. ${ }^{13-16)}$ The pattern of restenosis has an important prognostic impact on the need for recurrent target lesion revascularization (TLR). ${ }^{15)}$ Higher restenosis rates between $50 \%$ and $80 \%$ have been reported for the diffuse type of in-stent restenosis after balloon re-angioplasty. ${ }^{14-16)}$ That is why debulking is recommended in diffuse in-stent restenosis. In the present study, we discuss the early and mid-term results for excimer laser coronary angioplasty (ELCA) in the treatment of diffuse in-stent restenosis.

\section{MAterials ANd Methods}

The study was performed on 4 female and 19 male diffuse in-stent restenosis patients (mean age, $58 \pm 7$ years). All of the patients were symptomatic. The baseline characteristics are shown in Tables I and II.

Exclusion criteria: Focal in-stent restenosis, Safen vein graft, ejection fraction $<40 \%$, acute myocardial infarction, Stent diameter $<2.5 \mathrm{~mm}$, contraindication for the usage of heparin, aspirin, tyclopidin, and/or clopidogrel, and asymptomatic cases.

Procedure: The right femoral artery and $8 \mathrm{~F}$ guiding catheters (Cordis; Johnson and Johnson $n=11$ ), (Medtronic AVE Z, $n=12$ ) were used. The minimal lumen

Table I. Baseline Clinical Characteristics

\begin{tabular}{lcc}
\hline & $n=23$ & $\%$ \\
\hline Mean age & $58 \pm 7$ & \\
Sex & & \\
$\quad$ Male & 19 & 83 \\
$\quad$ Female & 4 & 17 \\
Diabetes mellitus & 1 & 4 \\
Hypercholesterolemia & 14 & 61 \\
Hypertension & 4 & 17 \\
Smoker & 12 & 52 \\
Previous MI & 5 & 22 \\
Previous CABG & 2 & 9 \\
LVEF (\%) & $51.4 \pm 4.6$ & \\
\hline CABG = coronary artery bypass & graft; \\
LVEF = left ventricular ejection & fraction; \\
MI = myocardial infarction.
\end{tabular}


Table II. Lesion Characteristics

\begin{tabular}{lcc}
\hline Characteristics & $n$ & $(\%)$ \\
\hline Lesion localization & & \\
LAD & 14 & 60 \\
RCA & 4 & 17 \\
LCx & 5 & 23 \\
Lesion length (mm) & $14.3 \pm 3$ \\
MLD (mm) & $0.9 \pm 0.4$ \\
\hline LAD =left anterior descending; RCA =ri \\
ght coronary artery; LCx =left circumflex \\
artery; MLD = minimum lumen diameter.
\end{tabular}

diameter (MLD) was determined by QCA. Activated clotting time was sustained at $>300$ seconds during the procedure. Clopidogrel and aspirin were administered three days before the operation to elective cases and a loading dose during the operation to nonelective cases. Written consent was obtained from the patients and the study was planned and conducted in accordance with the Helsinki Declaration.

Laser angioplasty protocol: The pulsed xenon chloride excimer laser (CVX-300, Spectranetics, Colorado Springs, CO) was operated at a wavelength of $308 \mathrm{~mm}$. The pulse duration was 135 seconds and the output was $200 \mathrm{~mJ} / \mathrm{pulse}$. The energy parameters were set at a fluence of $45 \mathrm{~mJ} / \mathrm{mm}^{2} ; 25 \mathrm{~Hz}$. The 'saline flush' ${ }^{17)}$ and 'pulse and retreat' ${ }^{18)}$ irradiating techniques were applied in each case. The operator then initiated irradiating, advancing the laser catheter at a speed of $0.5 \mathrm{~mm} / \mathrm{s}$ while at the same time an asistant injected saline at a rate of $5-7 \mathrm{~mL} / \mathrm{s}$.

The success of debulking, thorough crossing of the laser catheter the lesion was defined as absence of major dissection ( $\geq$ Type $C$ ) and no development of perforation. The success of the procedure was defined as the residual stenosis $\leq 20 \%$ post-procedure, the absence of perforation and major dissection, absence of death and infarction $(\mathrm{Q} /$ non $\mathrm{Q}$ wave $\mathrm{MI})$ during hospitalization and no need for revascularization (CABG, PTCA). Angina was classified according to the Canadian Cardiac Society (CCS) classification. Myocardial infarction was defined by the presence of two of the following: Chest pain of $\geq 30$ minutes duration, new Q wave or ST segment elevation $(\geq 1 \mathrm{mV})$ in at least two contiguous leads, or a more than two-fold increase in creatine kinase (CK) -MB above normal levels. Coronary dissection was defined by the classification of Huber, et $a l^{19)}$ and type $\mathrm{C}$ and above dissection were considered as major dissections. A major adverse cardiac event (MACE) was defined as death, a Q/non Q wave MI, or the need for revascularization. 
Statistical analysis: Values are presented as the mean \pm SD. The Wilcoxon Signed Ranks test was conducted to analyze the pre-ELCA and post-ELCA differences in MLD measurements. A $P<0.05$ was considered to be significant. The data were analysed using SPSS 10.05 for Windows.

\section{Results}

A 1.7 Vitesse $\mathrm{C}$ catheter was used in 18 patients, a 1.7 Vitesse $\mathrm{E}$ in 3 patients, and a 2.0 Vitesse $\mathrm{C}$ in 2 patients (Table III). A $60 \mathrm{~mJ} / \mathrm{mm}^{2}$ fluency-45 $\mathrm{Hz}$ repetition rate was used in 17 cases. In the other 6 cases, $60 \mathrm{~mJ} / \mathrm{mm}^{2}$ fluency and a $30-\mathrm{Hz}$ repetition rate were used. Successful lesion ablation was conducted using a laser catheter in all cases. PTCA was conducted in all cases with $7 \pm 2$ atm pressure, and the balloon/vessel ratio was $1.1 / 1$. The inflation time was $65 \pm 15$ seconds. MLD was $0.9 \pm 0.4 \mathrm{~mm}$ before ELCA, $1.8 \pm 0.9 \mathrm{~mm}(P<0.05)$ after ELCA, and $3.1 \pm 0.7 \mathrm{~mm}$ after PTCA. There were no major complications throughout the hospitalization period (range: $2 \pm 1$ days). The in-hospital MACE was $0 \%$ and the procedure success rate was $100 \%$. Type B distal dissection had developed in the distal end of the stent in $1(4.7 \%)$ case after ELCA and in 2 (8.7\%) cases after PTCA.

During the 6 month follow-up period, In $2(8.7 \%)$ of the cases of Q-wave MI and $2(8.7 \%)$ cases of angina during exercise (CCS II) were observed. Control angiography was done in 20 (87\%) of the cases. Restenosis was seen in 6 patients. Angiography was refused by 3 patients; their maximal exercise test was negative. The total angiography restenosis rate was $30 \%(6 / 20)$. CABG was applied to 3 of the cases, and 2 of the cases were treated by PTCA. The TLR was $22 \%$ (5/ 23) (Table IV).

Table III. Laser Parameters

\begin{tabular}{lc}
\hline Catheter Size & $n$ \\
1.7 Eccentric & 3 \\
1.7 Concentric & 18 \\
2.0 Concentric & 2 \\
Laser pulse rate & $13 \pm 3$ \\
MLD & \\
Before ELCA & $0.9 \pm 0.4 \mathrm{~mm}$ \\
After ELCA & $1.8 \pm 0.9 \mathrm{~mm}$ \\
After PTCA & $3.1 \pm 0.7 \mathrm{~mm}$ \\
\hline MLD = minimal lumen diameter; ELCA $=$ \\
excimer laser coronary angioplasty.
\end{tabular}


Table IV. Follow-up Results

\begin{tabular}{lcc}
\hline & $n$ & $\%$ \\
\hline Applied control angiography & 20 & 87 \\
Restenosis & 6 & 30 \\
TLR & 5 & 22 \\
\hline
\end{tabular}

$\mathrm{TLR}=$ target lesion revascularization.

\section{DISCUSSION}

In-stent restenosis is different than restenosis which develops after PTCA. The main factor here is neointimal hyperplasia. This tissue contains smooth muscle cells and intercellular supportive tissue. ${ }^{7)}$ Tissue with these properties is ideal ablative tissue for laser treatment. Saline infusion has significantly increased procedural safety. ${ }^{17,20)}$ In the treatment of diffuse in-stent restenosis, procedural success is quite high (99\%), although the long term results do not indicate the same success rates. Mehran compared IVUS with ELCA + PTCA and alone PTCA alone groups in the 107 in-stent restenosis patients. The 6 month follow-up rate of target vessel revascularization (TVR) for ELCA + PTCA was 21\%, and 38\% for PTCA. ${ }^{21)}$ Koster treated 440 in-stent restenosis patients with ELCA + PTCA. The vessel diameter ( $<3 \mathrm{~mm} n=161$ and $\geq 3 \mathrm{~mm} n=277)$ which indicated variation. Process success was $90-91 \%$; angioplasty success is $90-91 \%$. There were no statistical differences. In addition, the procedural success was not affected by the catheter diameter/vessel diameter ratio if it was greater or less than $0.8 .^{22)}$ Unlike ELCA, in rotablation atherectomy for the treatment of diffuse in-stent restenosis, the rate of procedural complication was found to be related with the burr/artery ratio. $^{23)}$ ELCA + PTCA was applied to 107 patients from the same group. By IVUS the plaque area was $4.2 \pm 1.8 \mathrm{~mm}^{2}$ before the procedure, ELCA decreased the plaque area to $2.7 \pm 1.1 \mathrm{~mm}^{2}$ alone and with the addition of PTCA plaque area decreased to $1.5 \pm 0.7 \mathrm{~mm}^{2}$. The death and Q-wave-MI rates were $0 \%$, and nonQ-wave MI was 5.7\%. ${ }^{24)}$ The study concluded that ELCA is an efficient and safe technique to debulk tissue in restenotic lesions and total occlusions within stents and the incidence of procedure related complications was low. ${ }^{24)}$ The procedural complication rates in Koster's series were Q-wave MI 0.5\%, non-Q-wave MI $2.7 \%$, tamponade $0.8 \%$, stent damage $0.5 \%$, perforation $0.9 \%$ (PTCA: $0.2 \%$ ), dissection $4.2 \%$ (PTCA: 9.3\%); most dissections occurred out of the stents and after the PTCA. ${ }^{22)}$ Reintervention during hospitalization was performed in $0.9 \%$ and CABG in $0.2 \%$ of the patients. ${ }^{22)}$ The LARS multicenter registry reported that ELCA in patients with complex in-stent restenosis is as safe and effective as bal- 
loon angioplasty alone. ${ }^{25)}$ There were no Q-wave myocardial infarctions or deaths during the procedure. ${ }^{25)}$ In this study, the TLR was $\left.30 \% .{ }^{25}\right)$ These complication rates are within acceptable ranges. In our study, there was 1 case (4\%) after ELCA and 2 cases (9\%) after PTCA which had minor dissection. In hospital MACE was $0 \%$.

Another study that combined ELCA with IVUS reported a $1.7 \mathrm{~mm}$ Eccentric Catheter reduced the stenosis ratio from $80 \pm 10 \%$ to $44 \pm 11 \%$ and a $2 \mathrm{~mm}$ Eccentric Catheter reduced the stenosis ratio to $11 \pm 12 \%(P<0.001){ }^{26)}$ When examined by IVUS, a smooth tissue ablation appearance was observed. No major complications or dissection in the stent wall occurred, however, in five cases dissections occurred out of the stents. ${ }^{26)}$ Dahn and Kuon using an eccentric catheter reported a reduced stenosis diameter from $84 \pm 14 \%$ to $23 \pm 14 \%(P<0.0018)$ in 39 patients. The procedural success rate was $99.8 \%$. At 6 months follow up the TLR was $12.8 \%$ and MACE was $0 \% .{ }^{27)}$ Both of these studies demonstrated that eccentric laser catheters were reliable in diffuse in-stent restenosis. In another study, rotational atherectomy and ELCA were compared and the TLRs were found to be $26 \%$ vs $28 \%$, respectively. ${ }^{28)}$

In our study, 2 (9\%) Q-wave MI cases and 2 (9\%) angina during exercise cases (CCS II) were observed during the 6 month follow-up period. Restenosis was observed in 6 patients. The angiographic restenosis rate was $30 \%(6 / 20)$, CABG was applied to 3 cases, and 2 cases were treated by PTCA. The TLR was $22 \%(5 / 23)$. Our results were similar to the results of other studies ${ }^{27-29)}$ (Table V).

These data suggest that ELCA is safe and effective for the treatment of instent restenosis and is associated with a high procedural success rate. Complications were extremely rare with this technique.

Table V. Results of Other Studies

\begin{tabular}{lcccc}
\hline Author & $\begin{array}{c}\text { Number } \\
\text { of } \\
\text { Patients }\end{array}$ & $\begin{array}{c}\text { Stenosis } \\
\text { Length } \\
(\mathrm{mm})\end{array}$ & $\begin{array}{c}\text { TVR (\%) } \\
\text { 6 month }\end{array}$ & $\begin{array}{c}\text { Recurrent } \\
\text { Restenosis } \\
6 \text { months }\end{array}$ \\
\hline Mehran $^{30}$ & 47 & $10.9 \pm 67$ & 21 & - \\
Köster $^{32}$ & 73 & $19.4 \pm 13$ & 33 & 52 \\
Haase $^{31}$ & 47 & $13.2 \pm 11$ & 28 & 52 \\
Dahm $^{27}$ & 39 & $14 \pm 9$ & 12.8 & 23 \\
Ilkay & 23 & $14.3 \pm 3$ & 22 & 30 \\
\hline
\end{tabular}

$\mathrm{TVR}=$ target vessel revascularization. 


\section{REFERENCES}

1. Mintz G, Popma J, Pichard A, et al. Arterial remodeling after coronary angioplasty: a serial intravascular ultrasound study. Circulation 1996; 94: 35-43.

2. Schwartz RS, Huber KC, Murphy JG, et al. Restenosis and the proportional neointimal response to coronary artery injury: Result in a porcine model. J Am Coll Cardiol 1992; 19: 267-74.

3. Sharma S, Duvvuri S, Dangas G, Kini A. Rotational atherectomy for in-stent restenosis: acute and long term results of first 100 cases. J Am Coll Cardiol 1998; 32: 1358-67.

4. Gordon P, Gibson C, Cohen D, Carrozza J, Kuntz R, Baim D. Mechanism of restenosis and redilatation within coronary stents: quantitative angiographic assessment. J Am Coll Cardiol 1993; 21: 1166-74.

5. Hoffmann R, Mintz GS, Dussaillant GR, et al. Patterns and mechanisms of in-stent restenosis: A serial intravascular ultrasound study. Circulation 1996; 94: 1247-54.

6. Mudra H, Regar E, Klauss V, et al. Serial follow up after optimized ultrasound-guided deployment of PalmazSchatz stents. Circulation 1997; 95: 363-70.

7. Mehran R, Mintz GS, Pichard A. The impact of vessel wall injury on in-stent restenosis-a serial quantitative angiographic and IVUS study. Circulation 1996; 94: 26.

8. Serruys PW, de Jaeger P, Kiemeneij F, et al. For the Benestent Study group. A comparison of balloon expandable-stent implantation with balloon angioplasty in patients with coronary heart disease. N. Engl J Med 1994; 331: 489-95.

9. Fischman DL, Leon MD, Baim DS, et al. For the Stent Restenosis Study Investigators. A randomized comparison of coronary-stent placement and balloon angioplasty in treatment of coronary artery disease. N Engl J Med 1994; 331: 496-501.

10. Tilli FV, Aliabadi D, Kinn JW. Real life stenting: A comparison of target vessel revasculazition in BenestentStress lesions to non Benestent-Stress lesions (abstract). Circulation 1996; 94: I-332.

11. Fenton SH, Fichman DL, Savage MP, et al. Long-term angiographic and clinical outcome after implantation of balloon expandable stents in aortocoronary saphenous vein grafts. Am J Cardiol 1994; 74: 1187-91.

12. Serruys PW, Emanuelsson H, van der Giessen W, et al. Heparin-coated Palmaz-Schatz stents in human coronary arteries. Early outcome of the Benestent-II Pilot study. Circulation 1996; 93: 412-22.

13. Bauters C, Banos JL, van Belle E, Mc Fadden EP, Lablanche JM, Bertrand ME. Six-month angiographic outcome after successful repeat percutaneous intervention for in-stent restenosis. Circulation 1998; 97: 318-21.

14. Yokoi H, Kimura T, Nakagawa Y, Nosaka H, Nobuyoshi M. Long term clinical and quantitative angiographic follow-up after Palmaz-Schatz stent restenosis. J Am Coll Cardiol 1996; 27(supplA): 224A.

15. Mehran R, Dangas G, Abizaid AS, et al. Angiographic patterns of in-stent restenosis. Circulation 1999; 100: 1872-8.

16. Eltchaninoff H, Koning R, Tron C, Gupta V, Cribier A. Balloon angioplasty for the treatment of coronary instent restenosis: Immediate results and 6 month angiographic recurrent restenosis rate. J Am Coll Cardiol 1998; 32: 9 .

17. Tcheng JE. Saline infusion in excimer laser coronary angioplasty. Semin Intervent Cardiol 1996; 1: 135-41.

18. Topaz O. A new safer lasing technique for laser-facilitated coronary angioplasty. J Intervent Cardiol 1993; 6: 297-306.

19. Huber MS, Money JF, Madison J, Money MR. Use of a morphologic classification to predict clinical outcome after dissection from coronary angioplasty. Am J Cardiol 1991; 68: 467-71.

20. Baumbach A, Haase KK, Rose C, Oberhoff M, Hanke H, Karsch K. Formation of pressure waves during in vitro excimer laser irradiation in whole blood and the effect of dilution with contrast media and saline. Laser Surg Med 1994; 14: 3-6.

21. Freitus JO, Berti SL, Bonfa JG, Speranza MS, Bongiovani HL. Cutting balloon angioplasty for intrastent restenosis treatment. Arg Bras Cardiol 1999; 72: 615-20.

22. Koster R, Christian W, Hamm A, et al. Laser angioplasty of restenosed coronary stents: Results of a multicenter surveillance trial. J Am Coll Cardiol 1999; 34: 25-32.

23. Colombo A, Ellis SG, Editorial. New frontiers in coronary stenting. Semin Intervent Cardiol 1998; 3: 57-63. 
24. Koster R, Hamm CW, TerresW, et al. Treatment of in-stent coronary restenosis by excimer laser angioplasty. Am J Cardiol 1997; 80: 1424-8.

25. Giri S, Ito S, Lansky JA, et al. Clinical and angiographic outcome in the Laser Angioplasty for Restenosis stents (LARS) Multicenter Registry. Cathet Cardiovasc Intervent 2001; 52: 24-34.

26. Koster R, Hamm CW, Terres W, Koschyk DH, Reimers J, Kahler J, Meinertz T. Acute results of ablation of coronary in-stent restenoses with eccentric excimer laser catheters. Z Kardiol 1998, 87: 537-44.

27. Dahn JB, Kuon E. High energy eccentric excimer laser angioplasty for debulking diffuse in-stent restenosis leads to better acute and 6 month follow-up results. J Invasive Cardiol 2000, 12: 335-42.

28. Mehran R, Dangas G,Mintz GS, et al. Treatment of in-stent restenosis with excimer laser coronary angioplasty versus rotational athrectomy: comparative mechanisms and results. Circulation 2000, 101; 2484-9.

29. Koster R, Kahler J, Terres W, et al. Six-month clinical and angiographic outcome after successful excimer laser angioplasty for in-stent restenosis. J Am Coll Cardiol 2000; 36: 69-74.

30. Mehran R, Mintz GS, Satler LF. Treatment of in-stent restenosis with excimer laser coronary angioplasty: Mechanism and results compared with PTCA alone. Circulation 1997; 96: 2183-9.

31. Haase J, Störger H, Hofmann M. Excimer laser angioplasty with adjunctive balloon dilatation versus dilatation alone for the treatment of in-stent restenosis. J Interven Cardiol 1999; 12: 513-8.

32. Köster R, Hamm CW, Terres W. Long-term results of laser angioplasty for in-stent restenosis. (abstract) J Am Coll Cardiol 1998; 31: 141A. 